\title{
Az ügyeleti ellátás útvesztői egy korszerütlen készítmény okozta iatrogenia kapcsán
}

\author{
Arányi Péter dr. - Tomcsányi János dr. \\ Budai Irgalmasrendi Kórház, Kardiológiai Osztály, Budapest
}

\begin{abstract}
A tiaziddiuretikumok, közöttük is mindenekelőtt a hydrochlorotiazid, a leggyakrabban alkalmazott antihipertenzív gyógyszereink közé tartoznak. Használata során azonban gyakori és akár súlyos következményekkel járó mellékhatásokkal lehet számolni, mint amilyen a hyponatraemia és hypokalaemia. Egy 66 éves nőbeteg esete kerül bemutatásra, akinek kardiológiai osztályra történt beutalására akut ST-elevációs myocardialis infarctus gyanúja miatt került sor, eszméletvesztést, illetve koponyatrauma ellátását követôen. A megtévesztő EKG-jelek (jelentős QT-megnyúlás: $\mathrm{QTc}=784 \mathrm{~ms}, \mathrm{~V}_{1-2}$-elvezetésekben J-pont eleváció mély negatív T-hullámokkal, egyéb elvezetésekben extrém széles pozitív T-hullámok) és emelkedett kreatinkináz- $(5392 \mathrm{U} / \mathrm{L})$ és troponin I- $(4,357 \mathrm{ng} / \mathrm{ml})$ szérumszintek hátterében akut myocardialis történés nem volt igazolható. Laborvizsgálatok alapján gravis hyponatraemiára és hypokalaemiára derült fény, amelyek hátterében elhúzódó gastroenteritises tünetek precipitáló hatása és a megelőzó hydrochlorotiazid antihipertenzív terápia volt véleményezhetô. A súlyos ioneltérések és egy vélhetően lezajlott tüneti epilepsziás görcsroham magyarázhatta az EKG-képet és laboreltéréseket. A differenciáldiagnosztika komplexitása mellett az eset a hydrochlorotiazid-kezelés valódi klinikai értékére és súlyos mellékhatásaira világít rá. Orv. Hetil., 2017, 158(11), 426-431.
\end{abstract}

Kulcsszavak: tiazidok, hydrochlorotiazid, tiazid indukálta hyponatraemia, hyponatraemia, ST-eleváció

\section{Differential diagnostic dilemmas after use of an out-of-date antihypertensive medication}

\section{Case report}

Hydrochlorothiazide became one of the most commonly prescribed first-line antihypertensive medication, though its use is often complicated with serious side-effects. A 66-year-old female patient with a history of hypertension had suffered a transient loss of consciousness, and referred to our cardiology unit with an ST-segment elevation and giant negative T-waves in V1-2 ECG leads, long QT-segment and elevated serum creatine-kinase (5392 U/L) and troponin I $(4,357 \mathrm{ng} / \mathrm{ml})$ levels. Acute myocardial infarction was not proven (later coronarography revealed preserved coronary circulation), but severe hyponatraemia and hypokalaemia was detected, explaining a possible symptomatic seizure, and which could be accounted for a $25 \mathrm{mg}$ daily hydrochlorothiazide antihypertensive treatment and - as a precipitating insult - a one-week history of gastroenteritis. The case-report presents a unique differential diagnostic question where thiazide-induced hyponatraemia and hypokalaemia resulted in a clinical picture sharing some similarities with acute myocardial infarction. This case underlines the serious side-effects of an inappropriately used common antihypertensive medication.

Keywords: thiazides, hydrochlorothiazide, thiazide-induced hyponatraemia, hyponatraemia, ST elevation

Arányi, P., Tomcsányi, J. [Differential diagnostic dilemmas after use of an out-of-date antihypertensive medication. Case report]. Orv. Hetil., 2017, 158(11), 426-431.

(Beérkezett: 2016. szeptember 26.; elfogadva: 2016. december 2.) 


\section{Rövidítések}

$\mathrm{ADH}=$ antidiuretikus hormon; $\mathrm{BMI}=$ body mass index; $\mathrm{CK}=$ kreatinkináz; CK-MB = szívizom-specifikus kreatinkináz-izoenzim („muscle-brain” típus); CT = komputertomográfia; $\mathrm{EKG}=$ elektrokardiográfia, elektrokardiogram; GOT = glutamát-oxálacetát-transzamináz; GPT = glutamát-piruvát-transzamináz; HCT = hydrochlorotiazid; $\mathrm{LDH}=$ laktát-dehidrogenáz; $\mathrm{M}=\mathrm{mol} / \mathrm{l} ; \mathrm{NCC}=\mathrm{Na}^{+} / \mathrm{Cl}^{-}$kotranszporter; $\mathrm{QTc}=$ korrigált QT-intervallum; STEMI = ST-elevációs akut myocardialis infarctus; $\mathrm{TIH}=$ tiazidindukált hyponatraemia

A tiazid típusú, illetve tiazidszerú diuretikumok (vagy egy másik nómenklatúra szerint a „distalis kanyarulatos csatorna diuretikumai"), közöttük is elsősorban a hydrochlorotiazid, 1958-ban történt gyógyszerpiacra kerülésük óta [1], közel 60 év alatt igen látványos népszerüségre tettek szert, és kétségkívül világszerte a leggyakrabban használt gyógyszereink közé tartoznak. Meglepő adat, hogy a hydrochlorotiazid 2008-ban az Amerikai Egyesült Államokban egy év alatt 134 millió felírt vénnyel a leggyakrabban rendelt antihipertenzív gyógyszer volt [2].

A kedvező antihipertenzív hatás mellett a tiaziddiuretikumok alkalmazása során igen gyakori és komoly következményekkel járó mellékhatásokkal kell ugyanakkor számolni, amelyek közül elsődleges a hyponatraemia és a hypokalaemia.

A hyponatraemia gyógyszer indukálta formáiban a tiazidkezelés áll az első helyen előfordulási gyakoriság alapján $[3,4]$. Egy kimutatás szerint az alapellátásban tiaziddiuretikumot szedő hypertoniás betegek mintegy 13,7\%-ánál alakul ki legalább enyhe fokú hyponatraemia [5]. A kórházi felvételre kerülő tiazidszedő betegeknél ugyanez az arány már sokkal magasabb, mintegy $38 \%$ is lehet [6].

A tiazidkezelés másik fontos mellékhatása a hypokalaemizáló hatás. A tiaziddiuretikummal kezelt betegek átlagos szérumkáliumkoncentrációja alacsonyabb a kontrollpopulációénál, illetve a kezelt betegek mintegy 8,5\%-a hypokalaemiás [5].

$\mathrm{Az}$ alábbiakban a tiazid indukálta elektrolit-egyensúly felborulásának egy szemléletes esete kerül bemutatásra, ahol a gyógyszermellékhatás váratlan módon egy kardiológiai osztály akut ST-elevációs infarktus ügyeletében került kiszűrésre.

\section{Esetismertetés}

A 66 éves nőbeteget sürgősséggel utalták a Budai Irgalmasrendi Kórház Kardiológiai Osztályára ST-elevációval járó akut myocardialis infarctus (STEMI) gyanújával. Megelőző kardiológiai szakvizsgálata a beutaló - jelen esetismertetésben nem megjelölt - másik intézményben történt, ahol elektrokardiográfia során QT-szakasz-megnyúlás mellett a $\mathrm{V}_{1}$ - és $\mathrm{V}_{2}$-elvezetésekben ST-eleváció, illetve negatív T-hullámok ábrázolódtak. Echokardiográ- fia során az interventricularis septum középső harmada volt hypokineticus. Laborvizsgálatok során jelentős mértékú szérumkreatinkináz- (5392 U/L) és cardialis troponin I- $(4,357 \mathrm{ng} / \mathrm{ml})$ szintek mutatkoztak. Anterior STEMI képe miatt sürgős koronarográfiát tartottak indokoltnak, előzetes egyeztetés alapján a beteget osztályunkra átvettük.

A felvétel közvetlen előzményéhez tartozik, hogy a beutaló intézménybe a beteget egy bizonytalan etiológiájú eszméletvesztést követően szállították. Baleseti sebészeti szakvizsgálat történt, külsérelmi nyomot nem észleltek, a készült koponya-CT-vizsgálat során a boltozati csontokon és az I-II. cervicalis csigolyákon fractura nem ábrázolódott, intracranialisan traumás szövődmény nem igazolódott. Epilepsziás roham gyanúja miatt ideggyógyászhoz irányították a beteget. Neurológiai szakvizsgálat fizikális eltérést nem talált, epilepsziás kóreredetet valószínúsítettek az eszméletvesztés hátterében, a betegnek kórházi kezelést ajánlottak fel, amit ő elutasított. Itt készült EKG alapján irányították tovább a beteget belgyógyász-kardiológushoz, aki a fentebb említett vizsgálatokat követően irányította tovább őt ST-elevációval járó akut myocardialis infarctusos fóvárosi betegek ellátására aznap kijelölt ügyeletünkbe.

Érkezésekor a sovány testalkatú nőbetegnél (BMI: $23,07 \mathrm{~kg} / \mathrm{m}^{2}$ ) enyhe dezorientáción kívül érdemi fizikális és idegrendszeri eltérés nem volt észlelhető. Akut myocardialis infarctusra utaló mellkasi panasz, dyspnoe nem volt. Az EKG-felvételen sinusrhythmus, keskeny QRS, körülbelül $70-80^{\circ}$-os QRS-tengelyállás mellett extrém QT-megnyúlás $(\mathrm{QTc}=784 \mathrm{~ms}$ ) ábrázolódott, $\mathrm{V}_{1-2}$-ben J-pont elevációval, mély negatív T-hullámokkal, egyéb elvezetésekben pozitív, extrém kiszélesedett T-hullámokkal (1. ábra). Szívultrahang vizsgálat során megtartott szisztolés balkamra-funkció mutatkozott relaxációs zavarral, a septum középső szegmensén merült fel hypokinesis, enyhe tricuspidalis és mitralis insufficientia Doppler-jele mellett. Laborleleteiból kiemelhető emelkedett „high sensitivity” kardialis troponin-T-szint (459 ng/L, referenciatartomány: <l4 ng/L), jelentősen

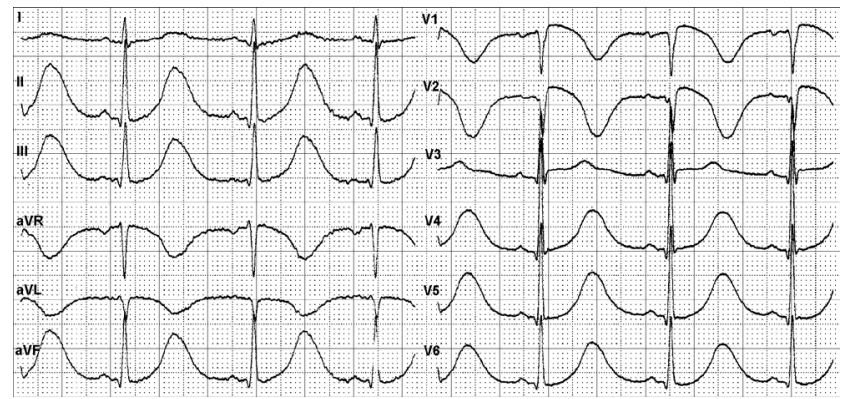

1. ábra

12 elvezetéses EKG-felvételkor 2,8 mM szérumkálium-koncentráció mellett (függőleges tengelyen $1 \mathrm{~mm}=0,1 \mathrm{mV}$, vízszintes tengelyen $1 \mathrm{~mm}=0,04 \mathrm{~s}$ ): sinusrhythmus, $70-80^{\circ}$ tengelyállás, keskeny QRS, megnyúlt QT-intervallum $(\mathrm{QTc}=784$ $\mathrm{ms}), \mathrm{V}_{1-2}$-ben J-pont-eleváció, $\mathrm{V}_{1-2}$-ben, aVL-ben negatív Thullámok, $V_{3-6}$ között pozitív T-hullámok 
emelkedett CK-szérum-enzimaktivitás $(4309$ U/L, referenciatartomány: 24-195 U/L, CK-MB izoenzim: 654 $\mathrm{ng} / \mathrm{ml}$, referenciatartomány: $<4,94 \mathrm{ng} / \mathrm{ml}$ ), gravis hyponatraemia (116 mM, referenciatartomány: 135$145 \mathrm{mM})$, hypokalaemia $(2,8 \mathrm{mM}$, referenciatartomány: $3,70-5,10 \mathrm{mM})$, mérsékelt leukocytosis $(25,24 \mathrm{G} / \mathrm{L}$, referenciatartomány: 4,4-11,3 G/L), emelkedett C-reaktív protein-szint $(69 \mathrm{mg} / \mathrm{L}$, referenciatartomány: $<5,0$ $\mathrm{mg} / \mathrm{l}$ ) mellett. LDH-szint $660 \mathrm{U} / \mathrm{L}$ (referenciatartomány: $<480 \mathrm{U} / \mathrm{L}$ ), GOT $120 \mathrm{U} / \mathrm{L}$ (referenciatartomány: 5-37 U/L), GPT $42 \mathrm{U} / \mathrm{L}$ (referenciatartomány: 5-4l U/L) volt. A klinikum, laborvizsgálatok eredményei és az EKG-kép alapján akut intervenciót nem tartottunk indokoltnak, az ioneltérések korrekcióját kezdtük meg. A kórházi kezelés első 24 órája alatt $10 \mathrm{mM}$-t emeltünk a szérumnátriumszinten (116 mM-ról 126 mM-re), majd a következő 24 óra alatt újabb $5 \mathrm{mM}$-rel $131 \mathrm{mM}$-re emelkedett a szérumnátriumszint, emisszió előtt pedig $135 \mathrm{mM}$-t mértünk. A hyponatraemia óvatos rendezését követően a beteg tudata feltisztult, ekkor derült fény a távolabbi anamnézisben szereplö hypertoniára, amelyre a beteg $5 \mathrm{mg}$ ramipril $+25 \mathrm{mg}$ hydrochlorotiazid kombinációs készítményt szedett évek óta, továbbá csak ekkor volt tisztázható körülmény, hogy a megelőző egy hétben a betegnek gastroenteritise zajlott, otthonában többször hányt és napokig híg diarrhoeája volt. A kialakult ionzavarral magyarázni lehetett a feltehetően lezajlott tüneti epilepsziás rohamot. Az elektrolit-egyensúly helyreállításával a látott EKG-eltérések (széles Thullámok és a megnyúlt QT-intervallum) regrediáltak (2-3. ábra). A differenciáldiagnosztikai céllal (tekintettel az atípusos EKG-eltérésekre és a magasan emelkedett felvételi szérum troponin-T-szintre, szem előtt tartva a beteg emelkedett cardiovascularis rizikófaktorait is) halasztottan elvégzett koronarográfia során a coronariákon csak érfal-egyenetlenségek mutatkoztak, érdemi szúkület nem ábrázolódott. A beteget néhány nap elteltével panaszmentesen emittáltuk otthonába, hypertoniájára a hydrochlorotiazid elhagyásával a továbbiakban ramiprilmonoterápiát javasoltunk.

\section{Megbeszélés}

A fentebb bemutatott esetünk a hydrochlorotiazid-kezelés igen gyakori mellékhatásának, a tiazid indukálta hyponatraemiának (TIH) egy szemléletes példája, ahol a betegnél feltehetốen egyéb hajlamosító tényezôk és a profúz diarrhoeával és hányással járó gastroenteritis precipitáló hatására alakultak ki a típusos idegrendszeri tünetek, és került sor a káros gyógyszermellékhatás felismerésére.

A tiazid indukálta hyponatraemia ismert klinikai tünetei a hányinger, hányás, fejfájás, zavartság, általános fáradtság és kognitív zavarok kialakulása, szédülés, eszméletvesztés, epilepsziás görcsroham jelentkezése, járásbizonytalanság és következményes esések és traumás sérülések $[7,8]$. Súlyos fokú vagy gyorsan kialakuló

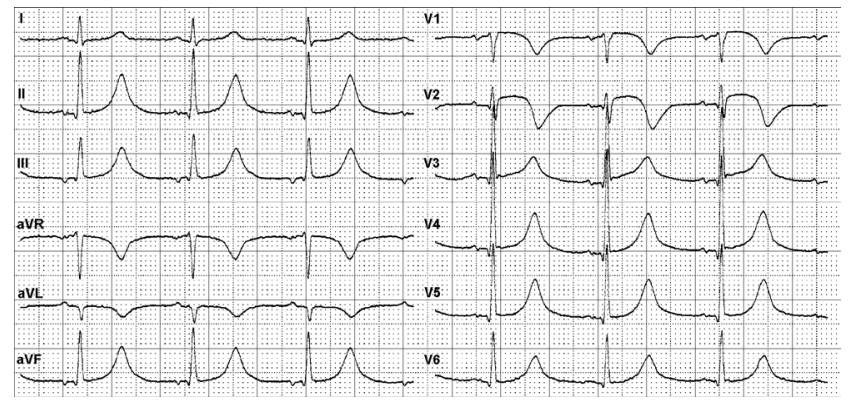

2. ábra

12 elvezetéses EKG 6 órával a felvételi EKG után, korrigált $\mathrm{K}^{+}$ szint $(4,4 \mathrm{mM})$ mellett (függóleges tengelyen $1 \mathrm{~mm}=0,1 \mathrm{mV}$, vízszintes tengelyen $1 \mathrm{~mm}=0,04 \mathrm{~s}$ ): sinusrhythmus, 70-80 tengelyállás, keskeny QRS, J-pont-eleváció $\mathrm{V}_{2-3}$-ban. Negatív Thullámok aVL-ben, $\mathrm{V}_{1-2}$-ben. T-hullámok szélessége, QT-intervallum hossza regrediált $(\mathrm{QTc}=66 \mathrm{~ms})$

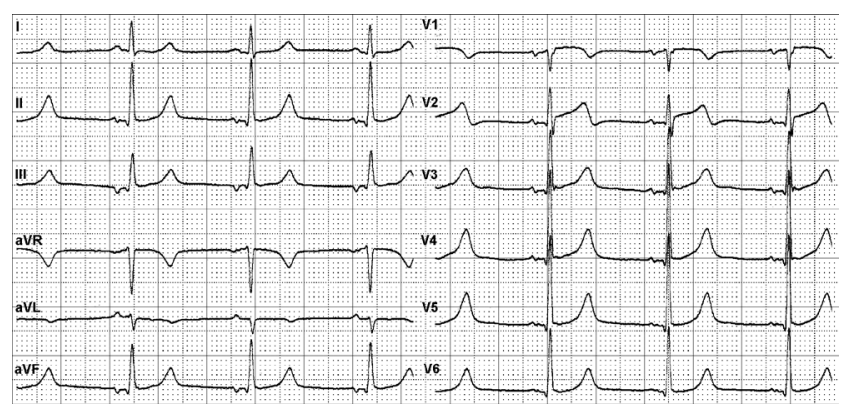

3. ábra

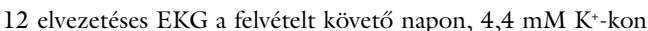
centráció mellett (függőleges tengelyen $1 \mathrm{~mm}=0,1 \mathrm{mV}$, víz szintes tengelyen $1 \mathrm{~mm}=0,04 \mathrm{~s}$ ): sinusrhythmus, $70-80^{\circ}$ ten gelyállás, keskeny QRS, J-pont-eleváció $\mathrm{V}_{2-3}$-ban. $\mathrm{V}_{2}$ T-hullám-inverzió regrediált. QT-megnyúlás megszúnt, QTc = $427 \mathrm{~ms}$

hyponatraemia cerebralis ödémát idézhet elő, akár kómát, tartós agyi károsodásokat, légzésleállást, koponyaalapi beékelődést okozva [9]. A tiaziddiuretikum-szedés mellett a hyponatraemia a betegek egy részében a kezelés első heteiben (egy 2014-es metaanalízis eredménye szerint átlagosan a kezelés 19. napján [8]) jelentkezik, míg másoknál (ahogy a fentebb bemutatott eset is mutatja) évek óta tartó gyógyszerszedés mellett is kialakulhat, ha egyéb hajlamosító tényező is fellép [7].

A TIH kialakulásában eddigi ismereteink alapján nemcsak a diuretikum közvetlen sóvesztést kiváltó hatása játszik szerepet, hanem az ezt kísérő csökkent szabadvízclearance [9]. A distalis kanyarulatos csatornák $\mathrm{Na}^{+}$/ $\mathrm{Cl}^{-}$kotranszporterének (NCC) gátlásával természetesen nemcsak a natriuresis nó, hanem a vízürítés is fokozódik, a relatív hypovolaemia az $\mathrm{ADH}$-elválasztást serkenti, amely egyrészt a szomjúságérzet növelésével hypotoniás folyadék fogyasztására ösztönzi a beteget [10], másrészt (mivel a tiazidkezelés - ellentétben a kacsdiuretikumokkal - a vese medullakoncentráló képességét nem érinti) a vese-gyújtő́csatornák aquaporincsatornáin keresztül a szabadvíz-reabszorpciót serkenti $[11,12]$. Az a tény ugyanakkor, hogy a tiaziddiuretikumot szedőknek csak bizonyos hányadában alakul ki hyponatraemia [5] és ösz- 
szességében a tiazidszedő populáció átlagos szérumnátriumszintje nem tér el a normál kontrollpopulációban mérhető átlagtól [4], arra utal, hogy hajlamosító tényezőknek lehet kiemelt szerepe a tiazid indukálta hyponatraemia kialakulásában, amelyek előzetes ismerete segítene a klinikusnak a veszélyeztetett betegek kiszűrésében [8]. Első helyen említendő a hyponatraemia kockázatának emelkedésében az idős életkor, amelyben feltehetően az ezzel együtt jelentkező egyéb komorbiditások jelentkezésének lehet döntő szerepe (mint például szívelégtelenség, krónikus veseelégtelenség, depresszió, dementia és a malignus betegségek) $[7,13]$. A 70 év feletti életkor mintegy négyszeres rizikóemelkedést jelent a hyponatraemia kialakulására vonatkozóan tiazidkezelés mellett [5]. Önálló rizikófaktornak számít a kísérő betegségek közül a 2-es típusú diabetes mellitus [6]. Eddigi ismereteink alapján még nem megmagyarázható módon a kisebb testalkatú, normális vagy annál kisebb BMI-vel (body mass index) rendelkező betegeknél nagyobb a hyponatraemia veszélye $[8,11,13]$. Természetesen fontos szerepe van egyéb, önmagában is hyponatraemizáló hatással bíró gyógyszerszedésnek (szelektív szerotoninreuptake-gátlók, nem szteroid gyulladáscsökkentők, benzodiazepinek stb.) [7]. Nőknél lényegesen gyakrabban írtak le hyponatraemiát tiazidkezelés mellékhatásaként $[14,15]$. Ugyanakkor a női nemnek a független rizikófaktorok közé sorolását azért kétségbe vonhatja az a tény, hogy egyes kimutatások szerint a tiaziddiuretikumokat gyakrabban rendelik nő, mint férfi hypertoniás betegeknek [11]. Mindenesetre néhány említett külső precipitáló tényezőt leszámítva, a hajlamosító tényezők kóroki szerepe még nagyrészt nem objektivizálható. A rizikótényezók együttes fennállásakor sem minden betegben alakul ki tiazid indukálta hyponatraemia, viszont akiknél már kialakult, egyes megfigyelések szerint a gyógyszerszedés elhagyását és az elektrolitszintek rendeződését követően folytatott ismételt gyógyszerszedés esetén újfent hyponatraemia jelentkezésére lehet számítani [16]. Mindez eddig még nem ismert, feltehetően genetikai tényezők kóroki szerepére világít rá, mely az elmúlt években egészen új kutatási távlatokat nyitott meg. Várhatóan az NCC és az aquaporincsatornák, továbbá egyéb, ezektől független renalis nátrium- és vízforgalomban szerepet játszó folyamatok pontos szabályozási mechanizmusainak és a háttérben meghúzódó génpolimorfizmusoknak a részletes megismerésével válik majd lehetővé a TIH pontosabb megértése, sőt ezen kutatások a hypertonia patomechanizmusával kapcsolatban, illetve egyénre szabott terápiáját illetően is új ismereteket vetítenek előre $[9,17]$.

Fontos következményekkel járó mellékhatása a tiaziddiuretikum-kezelésnek a hypokalaemia. Az NCC gátlásával kialakuló excesszív sóürítés, a distalis kanyarulatos csatornában megemelkedő $\mathrm{Na}^{+}$-mennyiség a fokozott $\mathrm{Na}^{+} / \mathrm{K}^{+}$kicserélődésen keresztül vezet $\mathrm{K}^{+}$-vesztéshez a gyưjtőcsatornákban $[8,18,19]$. Ezenkívül a hypokalaemia kialakulásának mechanizmusában még fontosabb tényező, hogy a krónikus diuretikus terápia mellett fellépó volumenhiány és $\mathrm{Na}^{+}$-vesztés fokozott aldoszteronprodukciót tart fenn, amely tartós kaliuresishez vezet [19, 20]. Ezt támasztja alá az a megfigyelés, hogy tiazid indukálta hypokalaemia mellett észlelhető hirtelen szívhalál előfordulási gyakorisága egy kísérő szelektív aldoszteronreceptor-antagonista kezeléssel nagyobb mértékben csökkenthető, mint pusztán káliumpótlás alkalmazásával [21]. A fentiek mellett a tiazidkezelés hatására csökken a tubulusfolyadékban a $\mathrm{Ca}^{2+}$-koncentráció, ez egyes megfigyelések szerint az elektrokémiai gradiens mentén vezet fokozott káliumürítéshez [22]. Végül egyes újabb megfigyelések szerint a tiazidok áramlásérzékeny, úgynevezett maxi $\mathrm{K}^{+}$-csatornák aktiválására is képesek, amely által szintén növelik a $\mathrm{K}^{+}$-kiválasztást [23].

A tiaziddiuretikumok dózisának növelésével egyértelmúen nő a hypokalaemizáló hatás (mind a hypokalaemia előfordulási gyakorisága, mind annak mértéke) [21, 24]. Egyértelmű hajlamosító tényezőket nem sikerült azonosítani, illetve a rendelkezésre álló adatok ellentmondásosak $[5,11]$, feltehetően a hyponatraemizáló hatással ellentétben egyszerű dózis-hatás összefüggésről beszélhetünk a hypokalaemiával kapcsolatban. $50 \mathrm{mg}$ napi hydrochlorotiazid bevitele mellett már mintegy $56 \%$-ban kialakuló hypokalaemiáról is beszámoltak egy helyen [25].

Hypokalaemia hatására az excitábilis szövetekben elektromos instabilitás észlelhető. A szívizomzatban megnő a kamrai ectopiák előfordulási esélye, malignus kamrai ritmuszavarok jelentkezhetnek, akár hirtelen szívhalálhoz vezetve [20]. Kamrai ectopiák kialakulásának esélye a HCT-vel kezelt hypertoniások mintegy egyharmadában megnő [26]. A súlyosabb hypokalaemia mindazonáltal meglehetősen ritka, így komolyabb szívritmuszavarok jelentkezésére is elvétve kell csak számítani, a hirtelen szívhalál relatív rizikója 1,5 tiaziddiuretikummal kezelt betegeknél placebokezeléssel való összevetésben [27].

Jelen esetnél szívritmuszavar nem volt észlelhető, a megtévesztő EKG-regisztrátum valójában a hypokalaemia jeleit ábrázolta a felvételi 2,8 mM szérumkáliumszint mellett a változatos megjelenésű repolarizációs zavar képével [28]. Széles alapú T-hullámok, extrém mértékben megnyúlt QT-intervallum mellett $\mathrm{V}_{\mathrm{l}-2}$-elvezetésekben Brugada-szerú J-pont-emelkedés és descendáló ST-eleváció és negatív T-hullám képe alakította ki a markáns repolarizációs eltéréseket.

Érdemesnek tartjuk a fenti esetet arra, hogy egy rövid értékelésbe bocsátkozzunk a hydrochlorotiazid-kezeléssel kapcsolatban. Az Európai Kardiológiai Társaság és az Európai Hypertonia Társaság legfrissebb, 2013-as ajánlásában még mindig szerepel, mint első vonalbeli javasolható antihipertenzívum, akár önmagában, akár egy kombinációs terápia részeként [29]. A hydrochlorotiazid az enyhébb hatású vérnyomáscsökkentő készítményeink közé tartozik. A szokásosan alkalmazott napi $12,5 \mathrm{mg}$, illetve $25 \mathrm{mg}$ dózisban önmagában meglehetősen sze- 
rény, átlagosan 6,5/4,5 Hgmm-es (szisztolés/diasztolés) vérnyomáscsökkenést eredményez [2], 10 Hgmm szisztolés vérnyomáscsökkentéshez átlagosan $26,4 \mathrm{mg}$ napi dózis szükséges [30]. Természetesen a dózis növelésével a vérnyomáscsökkentő hatás is növelhetô, amelynek az szab határt, hogy ezzel párhuzamosan a gyógyszer nemkívánatos mellékhatásai is nagyobb arányban és kifejezettebben jelentkeznek [31]. Megdöbbentő tény továbbá, hogy a szokásosan alkalmazott hydrochlorotiazid-dózisokra (napi 12,5-25 mg) vonatkozóan nincsen adat, hogy csökkentené a mortalitást vagy a cardiovascularis események kockázatát [32], hiszen minden ez irányú vizsgálatban vagy emelt (napi 50-100 mg) dózisban alkalmazták a szert $[33,34]$, vagy káliumspóroló diuretikumokkal való kombinációban (ahol a HCT döntő jelentőségű hypokalaemizáló hatása került ellensúlyozásra) $[21,35,36]$ számoltak csak be a mortalitásra vonatkozó kedvező adatokról, esetleg olyan tanulmányokban, ahol az egyes szerekre vonatkozó különbségtétel nélkül, általánosságban a diuretikumokról [37] vagy a tiaziddiuretikumokról összességében [38, 39] kerültek közlésre pozitív eredmények. Természetesen hozzá kell tenni, hogy ezek ellenére a szer használata mellett szól egyrészt, hogy más első vonalbeli antihipertenzívummal kombinációban erélyesebb vérnyomáscsökkentő hatással lehet számolni $[40,41]$, másrészt eredményes cardiovascularis rizikócsökkenés is tapasztalható, különösen, ha a kombináció a szer nemkívánatos mellékhatásait ellensúlyozó készítménnyel történik [24, 42$]$.

\section{Következtetés}

Részletezett esetünk igazi érdekessége és tudomásunk szerint az irodalomban eddig egyedülálló a jelen közlés abban a tekintetben, hogy egészen meglepő módon a hydrochlorotiazid gyógyszermellékhatása akut ST-elevációs myocardialis infarctus EKG- és laboreltéréseit utánozta. Másrészt az eset komplex differenciáldiagnosztikai problematikája, a nagy költségvonzatú ellátás tanulságai rávilágítanak a hydrochlorotiazid-kezelés árnyoldalaira. A fentebb részletezett nem kellően alátámasztott cardiovascularis kedvező hatások, összevetve a meglehetősen csekély (ezáltal számos más készítmény által kiváltható) vérnyomáscsökkentő képességével, szem előtt tartva a viszont nem elhanyagolható, fentebb illusztrált súlyos mellékhatásait, véleményünk szerint nem megkerülhető kérdéseket vet fel a jövőben a hydrochlorotiazid alkalmazhatóságának racionalitásáról.

Anyagi támogatás: A szerzők anyagi támogatásban nem részesültek.

Szerzöi munkamegosztás: A. P.: A bemutatott eset kórházi ellátásában való részvétel, irodalomkutatás, a kézirat szövegének elkészítése. T. J.: A bemutatott eset kórházi ellátásában való részvétel, a közlemény ötletének, elméleti hátterének megfogalmazása, irodalomkutatás, a kézirat szövegének elkészítése. A kézirat végleges változatát mindkét szerző elolvasta és azt jóváhagyta.

Érdekeltségek: A szerzőknek nincsenek érdekeltségeik.

\section{Irodalom}

[1] Freis, E. D., Wanko, A., Wilson, I. M., et al.: Treatment of essential hypertension with chlorotiazide (diuril); its use alone and combined with other antihypertensive agents. J. Am. Med. Assoc., 1958, 166(2), 137-140.

[2] Messerli, F. H., Makani, H., Benjo, A., et al.: Antihypertensive efficacy of hydrochlorotiazide as evaluated by ambulatory blood pressure monitoring: a meta-analysis of randomized trials. J. Am. Coll. Cardiol.,2011, 57(5), 590-600.

[3] Adrogué, H. J., Madias, N. E.: Hyponatremia. N. Engl. J. Med., 2000, 342(21),1581-1589.

[4] Clayton, J. A., Le Jeune, I. R., Hall, I. P.: Severe hyponatraemia in medical in-patients: aetiology, assessment and outcome. QJM, 2006, 99(8), 505-511.

[5] Clayton, J. A., Rodgers, S., Blakey, J., et al.: Thiazide diuretic prescription and electrolyte abnormalities in primary care. Br. J. Clin. Pharmacol., 2006, 61(1), 87-95.

[6] Al Qabtani, M., Alshahrani, A., Alskaini, A., et al.: Prevalence of hyponatremia among patients who used indapamide and hydrochlorotiazide: a single center retrospective study. Saudi J. Kidney Dis. Transpl., 2013, 24(2), 281-285.

[7] Liamis, G, Filippatos, T. D., Elisaf, M. S.: Thiazide-associated hyponatremia in the elderly: what the clinician needs to know. J. Geriatr. Cardiol., 2016, 13(2), 175-182.

[8] Barber, J., McKeever, T. M., McDowell, S. E., et al.: A systematic review and meta-analysis of tiazide-induced hyponatraemia: time to reconsider electrolyte monitoring regimens after tiazide initiation? Br. J. Clin. Pharmacol., 2015, 79(4), 566-577.

[9] Glover, M., Clayton, J.: Thiazide-induced hyponatraemia: epidemiology and clues to pathogenesis. Cardiovasc. Ther., 2012, 30(5), e219-e226.

[10] Liamis, G., Milionis, H., Elisaf, M.: A review of drug-induced hyponatremia. Am. J. Kidney Dis., 2008, 52(1), 144-153.

[11] Rodenburg, E. M., Hoorn, E. J., Ruiter, R., et al.: Thiazide-associated hyponatremia: a population-based study. Am. J. Kidney Dis., 2013, 62(1), 67-72.

[12] Haris, A., Radó, J.: Disorders of water and electrolite homeostasis. [A víz- és elektrolit-háztartás zavarai.] Medicina Könyvkiadó, Budapest, 2008.

[13] Chow, K. M., Szeto, C. C., Wong, T. Y., et al.: Risk factors for tiazide-induced hyponatraemia. QJM, 2003, 96(12), 911-917.

[14] Thoenes, M, Neuberger, H. R., Volpe, M., et al.: Antihypertensive drug therapy and blood pressure control in men and women: an international perspective. J. Hum. Hypertens., 2010, 24(5), 336-344.

[15] Ljungman, C., Kahan, T., Schiöler, L., et al.: Gender differences in antihypertensive drug treatment: results from the Swedish Primary Care Cardiovascular Database (SPCCD). J. Am. Soc. Hypertens., 2014, 8(12), 882-890.

[16] Friedman, E., Shadel, M., Halkin, H., et al.: Thiazide-induced hyponatremia. Reproducibility by single dose rechallenge and an analysis of pathogenesis. Ann. Intern. Med., 1989, 110(1), 2430 .

[17] Ji, W., Foo, J. N., O'Roak, B. J., et al.: Rare independent mutations in renal salt handling genes contribute to blood pressure variation. Nat. Genet., 2008, 40(5), 592-599.

[18] Roush, G. C., Kaur, R., Ernst, M. E.: Diuretics: a review and update. J. Cardiovasc. Pharmacol. Ther., 2014, 19(1), 5-13. 
[19] Ellison, D. H., Loffing, J.: Thiazide effects and adverse effects: insights from molecular genetics. Hypertension, 2009, 54(2), 196-202.

[20] Osadchii, O. E.: Mechanisms of hypokalemia-induced ventricular arrhythmogenicity. Fundam. Clin. Pharmacol., 2010, 24(5), 547-559.

[21] Siscovick, D. S., Raghunathan, T. E., Psaty, B. M., et al.: Diuretic therapy for hypertension and the risk of primary cardiac arrest. N. Engl. J. Med., 1994, 330(26), 1852-1857.

[22] Okusa, M. D., Velázquez, H., Ellison, D. H., et al.: Luminal calcium regulates potassium transport by the renal distal tubule. Am. J. Physiol., 1990, 258(2), F423-F428.

[23] Sansom, S. C., Welling, P. A.: Two channels for one job. Kidney Int., 2007, 72(5), 529-530.

[24] Messerli, F. H., Bangalore, S.: Half a century of hydrochlorotiazide: facts, fads, fiction, and follies. Am. J. Med., 2011, 124(10), 896-899

[25] Schnaper, H. W., Freis, E. D., Friedman, R. G., et al.: Potassium restoration in hypertensive patients made hypokalemic by hydrochlorotiazide. Arch. Intern. Med., 1989, 149(12), 2677-2681.

[26] Holland, O. B., Nixon, J. V., Kubnert, L.: Diuretic-induced ventricular ectopic activity. Am. J. Med., 1981, 70(4), 762-768.

[27] Hoes, A. W., Grobbee, D. E., Lubsen, J.: Sudden cardiac death in patients with hypertension. An association with diuretics and beta-blockers? Drug Saf., 1997, 16(4), 233-241.

[28] Diercks, D. B., Shumaik, G. M., Harrigan, R. A., et al.: Electrocardiographic manifestations: electrolyte abnormalities. J. Emerg. Med., 2004, 27(2), 153-160.

[29] Mancia, G., Fagard, R., Narkiewicz, K., et al.: 2013 ESH/ESC guidelines for the management of arterial hypertension: the Task Force for the Management of Arterial Hypertension of the European Society of Hypertension (ESH) and of the European Society of Cardiology (ESC). Eur. Heart J., 2013, 34(28), 21592219.

[30] Peterzan, M. A., Hardy, R., Chaturvedi, N., et al.: Meta-analysis of dose-response relationships for hydrochlorotiazide, chlorthalidone, and bendroflumetiazide on blood pressure, serum potassium, and urate. Hypertension, 2012, 59(6), 1104-1109.

[31] Szentes, V., Kovács, G., Dézsi, C. A.: Practice of antihypertensive treatment in diabetic patients with hypertension in Hungary. [Diabeteses hypertoniás betegek vérnyomáscsökkentő kezelésének hazai gyakorlata.] Orv. Hetil., 2014, 155(43), 1695-1700.

[32] Olde Engberink, R. H., Frenkel, W. J., van den Bogaard, B., et al.: Effects of tiazide-type and tiazide-like diuretics on cardiovascular events and mortality: systematic review and meta-analysis. Hypertension, 2015, 65(5), 1033-1040.

[33] Poblete, P. F., Kyle, M. C., Pipberger, H. V., et al.: Effect of treatment on morbidity in hypertension. Veterans Administration Cooperative Study on Antihypertensive Agents. Effect on the electrocardiogram. Circulation, 1973, 48(3), 481-490.

[34] Mortality after $101 / 2$ years for hypertensive participants in the Multiple Risk Factor Intervention Trial. Circulation, 1990, 82(5), 1616-1628.

[35] Medical Research Council trial of treatment of hypertension in older adults: principal results. MRC Working Party. BMJ, 1992, 304(6824), 405-412.

[36] Brown, M. J., Palmer, C. R., Castaigne, A., et al.: Morbidity and mortality in patients randomised to double-blind treatment with a long-acting calcium-channel blocker or diuretic in the International Nifedipine GITS study: Intervention as a Goal in Hypertension Treatment (INSIGHT). Lancet, 2000, 356(9227), 366372.

[37] Psaty, B. M., Lumley, T., Furberg, C. D., et al.: Health outcomes associated with various antihypertensive therapies used as firstline agents: a network meta-analysis. JAMA, 2003, 289(19), 2534-2544.

[38] Law, M. R., Morris, J. K., Wald, N. J.: Use of blood pressure lowering drugs in the prevention of cardiovascular disease: metaanalysis of 147 randomised trials in the context of expectations from prospective epidemiological studies. BMJ, 2009, 338, b1665.

[39] Wright, J. M., Musini, V. M.: First-line drugs for hypertension. Cochrane Database Syst. Rev., 2009, (3), CD001841.

[40] Metoki, H., Obara, T., Asayama, K., et al.: Differential effects of angiotensin II receptor blocker and losartan/hydrochlorotiazide combination on central blood pressure and augmentation index. Clin. Exp. Hypertens., 2015, 37(4), 294-302.

[41] Yamamoto, S., Okada, Y., Mori, H., et al.: Type 2 diabetes mellitus complicated by hypertension in Japanese patients: switching treatment from high-dose angiotensin II receptor blockers to losartan plus hydrochlorotiazide. Intern. Med., 2014, 53(12), 1283-1289.

[42] Zanchetti, A., Mancia, G.: Longing for clinical excellence: a critical outlook into the NICE recommendations on hypertension management - is nice always good? J. Hypertens., 2012, 30(4), 660-668.

(Arányi Péter dr., Budapest, Árpád fejedelem útja 7., 1023 e-mail: aranyi.p@gmail.com)

\title{
A rendezvények és kongresszusok híranyagának leadása
}

\author{
a lap megjelenése előtt legalább 40 nappal lehetséges, a 6 hetes nyomdai átfutás miatt. \\ Kérjük megrendelőink szíves megértését.
}

A híranyagokat a következő címre kérjük:

Orvosi Hetilap titkársága: edit.budai@akademiai.hu

Akadémiai Kiadó Zrt. 